\title{
Young Women Post-MI Have Higher Plasma Concentrations of Interleukin-6 Before and After Stress Testing
}

\author{
Cherie R Rooks, PhD, RD, ljeoma Ibeanu, MBBS, MPH, Amit Shah, MD, MSCR, Pratik \\ Pimple, MBBS, Nancy Murrah, RN, Lucy Shallenberger, MPH, Thaddeus Pace, PhD, J. \\ Douglas Bremner, MD, Paolo Raggi, MD, and Viola Vaccarino, MD, PhD \\ Department of Epidemiology, Rollins School of Public Health (C.R., I.J., P.P., N.M., L.S., V.V.); the \\ Department of Medicine, Division of Cardiology (A.J.S., V.V.); and the Department of Psychiatry \\ and Behavioral Sciences (T.P., J.D.B.), Emory University School of Medicine, Atlanta, GA; \\ Atlanta VAMC, Decatur, GA (J.D.B.); and the University of Alberta, Edmonton, Canada (P.R.)
}

\section{Abstract}

Objectives-Young women have poorer prognosis after myocardial infarction (MI) and a higher rate of mental stress-induced ischemia compared with similarly aged men. A higher inflammatory status may help explain these sex differences.

\begin{abstract}
Methods-We examined 98 patients (49 women and 49 men) age 18-59 years with recent MI (past 6 months). Women and men were matched for age, type of MI, and time since MI. Interleukin 6 (IL-6) concentrations were measured at baseline, after mental stress using a speech task, and after exercise/pharmacologic stress (60 and $90 \mathrm{~min}$ ). Depressive symptoms were measured with the Beck Depression Inventory (BDI-II) and angiographic coronary artery disease (CAD) severity was quantified with the Gensini score. Single-photon emission computed tomography (SPECT) was used to obtain a computerized measurement of stress-induced ischemia (summed difference score, or SDS) and determine whether severity of stress-induced ischemia affects the inflammatory response to stress. Analysis was stratified by the median age of 50 . Geometric mean concentrations of IL-6 were obtained from general linear regression models.
\end{abstract}

Results-In both age groups, women had less angiographic CAD and a similar level of conventional risk factors compared with men. Despite this, baseline IL-6 geometric means before both mental and physical stress were twice as high in women $\mathbf{5 0}$ years of age compared to agematched men ( 3.8 vs. $1.8 \mathrm{pg} / \mathrm{mL}, \mathrm{p}=0.001$, across both conditions), while they were similar in women and men age $>50$ years ( 2.3 vs. $2.2 \mathrm{pg} / \mathrm{mL}, \mathrm{p}=0.83$ ). After mental stress, IL-6 concentrations increased in both women and men in a similar fashion and remained twice as high in women $\leq 50$ years than men at both $60 \mathrm{~min}(5.4 \mathrm{vs.} 2.6 \mathrm{pg} / \mathrm{mL}, \mathrm{p}=0.002)$ and $90 \mathrm{~min}$ (5.9 vs. $3.4 \mathrm{pg} / \mathrm{mL}, \mathrm{p}=0.01$ ). No significant difference was found between women and men $>50$ years of

\footnotetext{
Address for Correspondence: Cherie Rooks, PhD, RD, Emory University Rollins School of Public Health, Department of Epidemiology, 1518 Clifton Road, NE, Atlanta, GA 30322; Phone: 404-712-8838, Fax: 404-727-8392, cherie.rooks@emory.edu. Publisher's Disclaimer: This is a PDF file of an unedited manuscript that has been accepted for publication. As a service to our customers we are providing this early version of the manuscript. The manuscript will undergo copyediting, typesetting, and review of the resulting proof before it is published in its final citable form. Please note that during the production process errors may be discovered which could affect the content, and all legal disclaimers that apply to the journal pertain.

Conflicts of Interest: None of the authors report conflict of interest relevant to this article.
} 
age at any time point after mental stress. Results were similar for physical stress. After accounting for SDS, IL-6 concentrations in young women remained higher after both mental and physical stress. Baseline IL-6 concentrations were not significantly related to inducible ischemia.

Conclusions-After MI, young women aged 50 years or younger, compared with age-matched men, have remarkably higher concentrations of inflammation at baseline and after both mental and physical stress, with a similar inflammatory response to both stressors. Sustained concentrations of inflammation in young women, not their response to stress, may contribute to their adverse outcomes post-MI.

\section{Keywords}

inflammation; interleukin-6; stress; ischemia; sex differences

\section{Introduction}

Coronary artery disease (CAD) is the leading cause of morbidity and mortality in the United States (Go et al., 2014). Substantial differences exist in the outcome of CAD by sex and age, as numerous studies have demonstrated that young and middle-aged women ( $<50$ years) who experience an acute myocardial infarction (AMI), have poorer outcomes than men of the same age (Andrikopoulos et al., 2006; Koek et al., 2006; Vaccarino et al., 1999; Vaccarino et al., 2009). This is in spite of the fact that women have less severe CAD and are more likely to have preserved systolic function and smaller infarcts when compared with their male counterparts (Rosengren et al., 2001; Vaccarino et al., 1999). The reasons for these differences are not yet clear.

Psychological stress can act as a trigger of acute coronary syndromes, such as a myocardial infarction (MI), in patients with underlying coronary artery disease (CAD) (Krantz et al., 1996; Mittleman et al., 1995; Mittleman et al., 1993). The pathophysiological mechanisms explaining the effects of stress on CAD risk may include sympathetic nervous system (SNS)-mediated increases in catecholamines and in cardiac demand, as well as plaque instability and myocardial ischemia (Krantz et al., 1996; Mittleman et al., 1995; Mittleman et al., 1993). Psychological stress also leads to increased inflammation in both healthy (Edwards et al., 2006b; Steptoe et al., 2002) and CAD populations (Kop et al., 2008), which may mediate the effects of stress on CAD incidence and progression (Kop, 2003). We recently found that young post-MI women (50 years old or younger) experience a higher rate of mental stress-induced myocardial ischemia (MSIMI) than age-matched men (Vaccarino et al., 2014), a difference that was not explained by traditional CAD risk factors. Women have been shown to exhibit higher circulating concentrations of inflammatory markers than men (Khera et al., 2005; Woloshin and Schwartz, 2005) and sex differences in cytokine response to physical or psychological stress have been described (Edwards et al., 2006a, b); so it is possible that sex differences in inflammation are implicated and potentially translate into poorer outcomes in young women after MI. To our knowledge however, no study has examined sex or age differences in the inflammatory response to psychological stress in patients with CAD. 
In a sample of young and middle aged ( $<50$ years) men and women who had experienced a recent MI (past 6 months), we examined changes in IL- 6 concentrations in the circulation before and after a standardized mental stress challenge in order to investigate the role that sex and age play in the inflammatory response to stress in this patient population. Since patients underwent myocardial perfusion imaging with both mental stress and a physical stressor (exercise or pharmacological stress test), we were also able to examine whether sex differences in inflammatory responses were confounded by myocardial ischemia.

\section{Methods}

\subsection{Participants}

The methods of the Myocardial Infarction and Mental Stress Study (MIMS) were described before (Vaccarino et al., 2014). Briefly, between July 2009 and April 2012, 98 patients were enrolled who were between the age of 38 and 59 years and had a documented history of MI within the previous 6 months. Men and women were matched for age ( \pm 2 years), type of MI (ST-elevation MI or non-ST-elevation MI) and time since the MI ( \pm 2 months). The diagnosis of MI was verified by medical record review based on standard criteria of troponin level increase and ECG changes (15). Subjects were excluded if they had unstable angina or acute MI within the past week, or a severe comorbid medical or psychiatric disorder that could interfere with study results, such as cancer, renal failure, current alcohol or substance abuse or schizophrenia. Subjects were also excluded if they weighed over 400 pounds (due to limits on the weight bearing of the nuclear stress test equipment), if they were pregnant or breastfeeding, or if they were currently using postmenopausal hormone therapy or psychotropic medications other than antidepressants. Finally, patients were excluded if they were unable to exercise on a treadmill, based on a score < 5 METs (Metabolic Equivalents) on the Duke Activity Status Index (DASI), which identifies patients who cannot exercise to heart rate targets (Hlatky et al., 1989).

\subsection{Study Design}

Subjects underwent two separate days of testing. All testing was done after an overnight fast, and anti-ischemic medications, including beta-blockers, calcium channel blockers and long-acting nitrates were held for 24 hours prior to testing. Patients were not included in the study if they had symptoms or signs of acute illness. Sociodemographic and psychosocial data were collected at the first visit prior to the stress testing. At the end of the study protocol, medical records were abstracted for clinical information, including ejection fraction and catheterization data. The study protocol was approved by the Emory University Institutional Review Board, and informed consent was obtained from all participants.

\subsection{Mental and Physical Stress Procedures}

The procedures for mental and physical stress testing have previously been described (Vaccarino et al., 2014). Briefly, mental and physical stress testing was conducted on two separate days, within one week of each other; the order of the stressors was counterbalanced. For mental stress, participants were asked to imagine a real-life stressful situation, such as a close relative been mistreated in a nursing home, and asked to make up a realistic story around this scenario. They were given two minutes to plan the story and prepare a statement 
and three minutes to present it in front of a video camera and an audience wearing white coats. For physical stress, subjects were submitted to a Bruce protocol by walking on the treadmill, with exercise target set at $85 \%$ of maximum predicted heart rate based on the patient's sex and age. For subjects $(n=16)$ who were unable to reach the heart rate target despite scoring $\geq 5$ METs on the DASI during screening, we performed a pharmacological stress test with regadenoson (Astellas, Northbrook, IL), an adenosine receptor agonist. Subjective ratings of distress were measured before and after mental stress with the Subjective Units of Distress Scale (SUDS). The SUDS measures distress on a linear scale of 0 to 100 , with 100 being the highest level of distress (Wolpe, 1973).

\subsection{Measurements}

2.4.1. Measurement of Inflammatory Responses-Interleukin-6 (IL-6) was tested from blood samples collected before (two separate baseline measurements) and after mental and physical stress conditions. Blood samples were obtained from a catheter placed in the arm and collected in EDTA tubes, placed immediately on ice, and centrifuged at $4 \mathrm{C}$ for 10 minutes at $3000 \mathrm{rpm}$. IL-6 was tested from plasma samples aliquoted from whole blood collected before, 60 and 90 minutes after mental and physical stress. Plasma collection time points were selected based on prior studies of physical and mental stress testing (Edwards et al., 2006b; Mendham et al., 2011; Moldoveanu et al., 2000; Steptoe et al., 2001), including work by us (Pace et al., 2006; Pace et al., 2009; Pace et al., 2010), indicating that the IL-6 response to stress becomes most apparent one hour after mental and physical stress onset. IL-6 was assessed using commercially available ELISA kits from R and D Systems (R \& D) Systems, Minneapolis, MN.

2.4.2. Myocardial Perfusion Imaging-Subjects underwent three SPECT myocardial perfusion imaging scans following injection of sestamibi radiolabelled with technetium-99m $\left(\left[{ }^{99} \mathrm{~m} \mathrm{Tc}\right]\right)\left(\left[{ }^{99 \mathrm{~m}} \mathrm{Tc}\right]-\right.$ sestamibi$)$, at rest, during mental stress, and during physical stress on a dedicated ultra-fast solid-state camera (Discovery NM 530c, GE, Milwaukee, WI) without attenuation correction (Esteves et al., 2009). For the resting scan, after confirmation of proper positioning, myocardial perfusion images were acquired after the injection of 10-15 $\mathrm{mCi}$ of [ $\left.{ }^{99 \mathrm{~m}} \mathrm{Tc}\right]$-sestamibi according to body weight. For mental stress, 30-45 $\mathrm{mCi}$ of $\left[{ }^{99 \mathrm{~m}} \mathrm{Tc}\right]$-sestamibi were injected one minute after the onset of the public speech; while for exercise stress the radiopharmaceutical was injected at peak exertion following the Bruce protocol. Stress images were acquired $45-60$ minutes after $30-45 \mathrm{mCi}$ of [ $\left.{ }^{99 \mathrm{~m}} \mathrm{Tc}\right]$-sestamibi injection using previously described methodology (Walkers et al., 2000).

Myocardial perfusion was quantified by means of the Emory Cardiac Toolbox, a software program that provides objective (operator-independent) quantitative assessment of perfusion with established validity and reproducibility (Garcia et al., 1987; Garcia et al., 2007). Briefly, the three-dimensional tracer uptake distribution in the left ventricular chamber was oriented along the short axis and sampled onto a two-dimensional polar map. A summed score, quantifying the extent and severity of perfusion defects across 17 segments of the myocardium at rest and during stress, was computed by the software according to published methodology (Garcia et al., 1987). In each region, defect severity was quantified using a 4point scale from normal (score $=0$ ) to absent perfusion (score $=4$ ). The regional severity 
scoring was then summed up across the 17 myocardial segments yielding a total score.

Separate scores were obtained for the rest images (summed rest score, SRS) and the stress images (summed stress score, SSS). The Summed Difference Score is defined as SSS minus SRS. A positive SDS is indicative of the presence of myocardial ischemia.

2.4.3. Other Measurements-Medical history information, including medication use, was collected by a research nurse. Body mass index (BMI), calculated as weight in kilograms divided by the square of the height in meters, was analyzed as a continuous variable. Blood samples were collected to examine glucose and lipid profile after an overnight fast. Angiographic data were obtained from the coronary angiogram performed in conjunction with the index MI. CAD severity was quantified using the Gensini semiquantitative angiographic scoring system (Gensini, 1983), which takes into account the degree of luminal narrowing along with a multiplier for specific coronary tree locations. Depressive symptoms were measured using the Beck Depression Inventory II (BDI-II) (Beck et al., 1996), which has previously been shown to be valid and reliable in cardiac patients. Lifetime history of depression was assessed using the Structured Clinical Interview for DSM IV (SCID), which yields a clinical diagnosis of major depression (First et al., 1995).

\subsection{Statistical Analysis}

Statistical analysis was performed using SAS software version 9.3 (SAS Institute). Analyses were conducted using mixed model analysis with repeated measures. Analyses were stratified by sex and median age ( 50 or $>50$ years of age). IL- 6 concentrations were logtransformed to improve normality and geometric means were obtained from mixed model analysis. All analyses were conducted before and after adjusting for cardiovascular risk factors (i.e., age, income, race, smoking status, HDL cholesterol, statin use, BMI), depressive symptoms, and CAD severity. To determine whether inflammatory responses to stress (change from baseline) are influenced by myocardial ischemia, a subsequent model further adjusted for Summed Difference Score, a quantitative measure of perfusion deficit. We also examined, separately, whether baseline IL-6 concentrations were related to myocardial ischemia with physical or mental stress. Lastly, since responses to pharmacological stress may differ from exercise stress, we repeated the analysis after removing participants who underwent pharmacological stress testing. Significance level was set at 0.05 , two sided.

\section{Results}

The study sample included 98 patients ( 49 women and 49 men) with a median age of 50 years. The demographic, lifestyle, and clinical characteristics of the population have been previously described (Vaccarino et al., 2014). Women $\mathbf{5 0}$ years of age were more likely to be black and to be smokers compared to age-matched men; they also had more depressive symptoms measured with the BDI-II (13.88 $\pm 9.52 \mathrm{SD}$ vs $8.00 \pm 6.51 \mathrm{SD}, \mathrm{p}=0.02)$ and higher ratings of subjective distress before mental stress measured with the SUDS (28.25 \pm 32.69 SD vs. $10.43 \pm 15.66 \mathrm{SD}, \mathrm{p}=0.02$ ). These differences were not noted among patients $>50$ years of age. 


\subsection{Baseline Plasma Interleukin-6 Concentrations}

Mean plasma IL- 6 concentrations (averaged across both mental and physical stress baseline values) varied little according to most patient characteristics when taking into account corrections for multiple comparisons (Table 1). However, baseline IL-6 concentrations were markedly higher in young women compared to age-matched men $(\mathrm{p}=0.001)$, while no sex difference was observed among individuals $>50$ years of age (age $\times$ sex interaction: $\mathrm{p}=0.03$ ) (Figure 1, Table 2). After accounting for demographic and cardiovascular risk factors, previous revascularization, CAD severity, and depressive symptoms, baseline plasma IL-6 concentrations remained significantly higher in young women compared to age-matched men (Table $2, p<0.001$ ), while they remained similar between men and women $>50$ years of age ( $\mathrm{p}=0.88$ ). After accounting for baseline SUDS in a separate model, IL-6 concentrations remained significantly higher in young women (3.87, 95\% CI: 2.89, 5.18) compared to young men $(1.77,95 \%$ CI: $1.33,2.36)$.

Inflammatory Responses to Stress-Plasma IL-6 concentrations increased significantly with both mental stress (time effect: $\beta=0.003$, $\mathrm{p}<0.001$ ) and physical stress (time effect: $\beta=0.003, p<0.001$ ). IL- 6 concentrations remained significantly higher 60 and 90 minutes after both mental (Figure 2A) and physical stress (Figure 3A) in young women compared to age-matched men ( $p$ 's $<0.05$ ), while there were no differences between older women and men at any time point (Figures $2 \mathrm{~B}$ and $3 \mathrm{~B}$ ). These sex differences persisted after accounting for demographic and cardiovascular risk factors, previous revascularization, CAD severity, and depressive symptoms (p's < 0.05) (Table 2). Adjusting for stress-induced ischemia, as measured by SDS, also did not affect the sex differences in IL- 6 concentrations at 60 and 90 minutes post-stress (Table 2). In a separate model, accounting for functional capacity (DASI score) did not attenuate sex differences in IL-6 for mental stress (60 minutes: $\mathrm{p}=0.01$, and 90 minutes: $\mathrm{p}=0.02$ ) or physical stress ( 60 minutes: $\mathrm{p}=0.001$, and 90 minutes: $\mathrm{p}=0.002$ ). Similarly, after accounting for baseline SUDS score, sex differences in young women compared to young men remained essentially unchanged. Furthermore, excluding participants that underwent Lexiscan from the physical stress analysis did not attenuate sex differences between young women and men both at 60 minutes ( 2.52 vs. 1.21 , $\mathrm{p}<0.001$ ), and at 90 minutes (2.63 vs. $1.29, \mathrm{p}=0.002)$ after exercise stress. Results remained similar also for older women and men ( 2.32 vs. $2.33, \mathrm{p}=0.87$, and 2.69 vs. $2.50, \mathrm{p}=0.95$, respectively).

The age $\times$ sex interaction for mental stress was marginally significant $(\beta=0.57, \mathrm{p}=0.06)$ and statistically significant for physical stress $(\beta=0.68, p=0.02)$. Women aged 50 years and younger had higher IL- 6 concentrations across time for both mental (gender effect: $\beta=$ $-0.68, \mathrm{p}=0.002)$ and physical stress $(\beta=-0.63, \mathrm{p}=0.002)$, with no significant sex $\times$ age $\times$ time interaction. Baseline plasma concentrations of IL- 6 were not significantly related to inducible ischemia measured by means of the SDS after either mental $(\beta=0.14, \mathrm{p}=0.07)$ or physical stress $(\beta=-0.05, \mathrm{p}=0.65)$; results were similar when men and women were examined separately. 


\section{Discussion}

In this study we found that among CAD patients less than 6 months post MI, younger women ( $\$ 50$ years of age) exhibited remarkably higher circulating concentrations of IL-6 before and after mental and physical stress, compared to age-matched men. The higher concentrations of IL-6 in young women compared to age-matched men were independent of CAD risk factors and CAD severity. On the other hand, young women and men did not differ in their inflammatory response to either mental or physical stress, since the increase in circulating concentrations of IL-6 as a result of mental stress was similar across both genders. Myocardial ischemia, measured by SDS, was not shown to confound these results, nor were baseline IL- 6 concentrations related to propensity toward ischemia with either mental or physical stress.

To date, only the study by Kop et al. (Kop et al., 2008) examined inflammatory responses to both mental and physical stress in a CAD population. In that study, which included patients with documented CAD after successful percutaneous coronary intervention, both mental stress (mental arithmetic and anger recall) and physical stress (treadmill protocol) increased C-reactive protein (CRP), IL-6 and intercellular adhesion molecule-1 (sICAM1), but the effects of physical stress on inflammatory responses were more robust compared to mental stress. Similar to the study by Kop et al., in the present study we observed stress-induced increases in inflammation, which were independent from occurrence of ischemia. In our study we found that both mental and physical stress increase IL-6 concentrations in a similar fashion. These differences may be explained by differences in study populations, especially the younger patient population included in our study (Ford et al., 2003; Woloshin and Schwartz, 2005) and the fact that we measured IL-6 at 60 and 90 minutes after stress rather than at 3 minutes and 30 minutes, as measured by Kop et al. Previous research suggests that both physical- and psychological stress-induced elevations in IL-6 concentrations in the circulation are highest 30 minutes to 2 hours post-stress (Edwards et al., 2006b; Mendham et al., 2011; Moldoveanu et al., 2000; Pace et al., 2006; Pace et al., 2009; Pace et al., 2010; Steptoe et al., 2001), which may explain the similarity in IL-6 concentrations after mental and physical stress.

Our study extends the existing literature by examining sex differences and conducting stratified analyses according to age. We observed remarkably higher concentrations of IL-6 before and after stress in young women compared to age matched men that remained after adjusting for risk factors. The underlying explanation for these age and sex differences in inflammation is unknown. A previous study similarly reported higher basal inflammatory activation, as measured by C-reactive protein, in young women compared to similarly aged men starting at age 16 , potentially due to the onset of menarche with resulting increase in steroid hormones such as estrogen (Ford et al., 2003). The post-menopausal decline in serum estrogen may explain why no sex difference was observed in IL-6 concentrations in older women and men (Albert and Ridker, 2006; Ford et al., 2004). It is also likely that women anticipate stress more than men (Fraser et al., 2008). In our sample, there was higher anticipatory distress in young women compared to young men. On the other hand, accounting for pre-stress SUDS scores did not alter IL-6 concentrations before or after stress. 
Inflammation plays an integral role in the pathophysiology of CAD (Ross, 1993, 1999). In CAD patients, mental and physical stress can act as triggers of acute coronary syndromes, such as myocardial infarction, but these increases in inflammation are not related to myocardial ischemia, as documented in the study by Kop et al. and in our study. In this same sample of CAD patients, we showed previously that young women had a higher prevalence of myocardial ischemia induced by mental stress compared to age-matched men before and after accounting for sociodemographic and life-style factors, coronary artery disease severity, and depression (Vaccarino et al., 2014). Since baseline inflammation was not related to ischemia in the current analysis, alternative mechanisms must be at play to explain gender differences in mental stress-induced ischemia, such as abnormal coronary vasoactivity, microvascular and endothelial dysfunction.

A limitation of the current study is the absence of a control group without CAD to examine what effect stressors have in the absence of pre-existing CAD. Nevertheless, the gender differences remained after accounting for multiple risk factors, as well as disease severity and inducible ischemia. In addition, IL-6 was the only cytokine measured in this study, therefore limiting a thorough analysis of inflammation. On the other hand, IL-6 is one of the inflammatory biomarkers most consistently associated with the psychological stress response (Steptoe et al., 2007). Finally, the small sample precludes the ability to link our results to health outcomes. Yet this is the first study to report sex differences in inflammation concentrations before and after both mental and physical stress in a CAD population. Moreover, in this controlled study, women and men were matched on several important factors, which support the validity of our findings.

In conclusion, we found that young women with a recent history of AMI have circulating concentrations of IL-6 that are twice as high at baseline, but a similar IL-6 response to mental and physical stress, compared with young men. Future studies should investigate whether these differences in inflammatory state translate into outcome differences, and whether they help explain why young women post-MI have a higher mortality than men of similar age. These results also suggest that interventions that mitigate inflammatory responses to stress, such as regular physical activity, may be especially beneficial for young women post-MI.

\section{Acknowledgments}

Sources of Funding: This work was supported by the National Institutes of Health R21HL093665, R21HL093665-01A1S1, R01 HL109413, 2R01 HL068630, 2K24HL077506, K24 MH076955, R01 MH056120, R01 HL088726, and P01 HL 101398. The sponsors of this study had no role in the design and conduct of the study; collection, management, analysis, and interpretation of the data; and preparation, review, or approval of the manuscript.

\section{References}

Albert MA, Ridker PM. C-reactive protein as a risk predictor: do race/ethnicity and gender make a difference? Circulation. 2006; 114:e67-e74. [PubMed: 16880331]

Andrikopoulos GK, Tzeis SE, Pipilis AG, Richter DJ, Kappos KG, Stefanadis CI, Toutouzas PK, Chimonas ET. Younger age potentiates post myocardial infarction survival disadvantage of women. Int. J. Cardiol. 2006; 108:320-325. [PubMed: 15963582] 
Beck, AT.; Steer, RA.; Brown, GK., editors. BDI-II. Beck Depression Inventory. San Antonio, TX: The Psychological Corporation; 1996.

Edwards KM, Burns VE, Ring C, Carroll D. Individual differences in the interleukin-6 response to maximal and submaximal exercise tasks. Journal of sports sciences. 2006a; 24:855-862. [PubMed: 16815780]

Edwards KM, Burns VE, Ring C, Carroll D. Sex differences in the interleukin-6 response to acute psychological stress. Biological psychology. 2006b; 71:236-239. [PubMed: 16098655]

Esteves FP, Raggi P, Folks RD, Keidar Z, Askew JW, Rispler S, O’Connor MK, Verdes L, Garcia EV. Novel solid-state-detector dedicated cardiac camera for fast myocardial perfusion imaging: multicenter comparison with standard dual detector cameras. J. Nucl. Cardiol. 2009; 16:927-934. [PubMed: 19688410]

First, MB.; Spitzer, RL.; Williams, JBW.; Gibbon, M. Structured Clinical Interview for DSM IV Patient Edition (SCID-P). Washington, D.C.: American Psychiatric Press; 1995.

Ford ES, Giles WH, Mokdad AH, Myers GL. Distribution and correlates of C-reactive protein concentrations among adult US women. Clinical chemistry. 2004; 50:574-581. [PubMed: 14709450]

Ford ES, Giles WH, Myers GL, Rifai N, Ridker PM, Mannino DM. C-reactive protein concentration distribution among US children and young adults: findings from the National Health and Nutrition Examination Survey, 1999-2000. Clinical chemistry. 2003; 49:1353-1357. [PubMed: 12881452]

Fraser SN, Rodgers WM, Daub B. Psychosocial Correlates of Cardiovascular Reactivity to Anticipation of an Exercise Stress Test Prior to Attending Cardiac Rehabilitation: A Preliminary Test1. Journal of Applied Biobehavioral Research. 2008; 13:20-41.

Garcia EV, DePuey EG, DePasquale EE. Quantitative planar and tomographic thallium-201 myocardial perfusion imaging. Cardiovasc. Intervent. Radiol. 1987; 10:374-383. [PubMed: 3123063]

Garcia EV, Faber TL, Cooke CD, Folks RD, Chen J, Santana C. The increasing role of quantification in clinical nuclear cardiology: the Emory approach. Journal of Nuclear Cardiology. 2007; 14:420 432. [PubMed: 17679051]

Gensini GG. A more meaningful scoring system for determining the severity of coronary heart disease. Am J Cardiol. 1983; 51:606. [PubMed: 6823874]

Go AS, Mozaffarian D, Roger VL, Benjamin EJ, Berry JD, Blaha MJ, Dai S, Ford ES, Fox CS, Franco S, Fullerton HJ, Gillespie C, Hailpern SM, Heit JA, Howard VJ, Huffman MD, Judd SE, Kissela BM, Kittner SJ, Lackland DT, Lichtman JH, Lisabeth LD, Mackey RH, Magid DJ, Marcus GM, Marelli A, Matchar DB, McGuire DK, Mohler ER 3rd, Moy CS, Mussolino ME, Neumar RW, Nichol G, Pandey DK, Paynter NP, Reeves MJ, Sorlie PD, Stein J, Towfighi A, Turan TN, Virani SS, Wong ND, Woo D, Turner MB, American Heart Association Statistics, C., Stroke Statistics, S. Heart disease and stroke statistics--2014 update: a report from the american heart association. Circulation. 2014; 129:e28-e292. [PubMed: 24352519]

Hlatky MA, Boineau RE, Higginbotham MB, Lee KL, Mark DB, Califf RM, Cobb FR, Pryor DB. A brief self-administered questionnaire to determine functional capacity (The Duke Activity Status Index). Am. J. Cardiol. 1989; 64:651-654. [PubMed: 2782256]

Khera A, McGuire DK, Murphy SA, Stanek HG, Das SR, Vongpatanasin W, Wians FH Jr, Grundy SM, de Lemos JA. Race and gender differences in C-reactive protein levels. J. Am. Coll. Cardiol. 2005; 46:464-469. [PubMed: 16053959]

Koek HL, de Bruin A, Gast F, Gevers E, Kardaun JW, Reitsma JB, Grobbee DE, Bots ML. Short- and long-term prognosis after acute myocardial infarction in men versus women. Am J Cardiol. 2006; 98:993-999. [PubMed: 17027558]

Kop WJ. The integration of cardiovascular behavioral medicine and psychoneuroimmunology: new developments based on converging research fields. Brain, behavior, and immunity. 2003; 17:233237.

Kop WJ, Weissman NJ, Zhu J, Bonsall RW, Doyle M, Stretch MR, Glaes SB, Krantz DS, Gottdiener JS, Tracy RP. Effects of acute mental stress and exercise on inflammatory markers in patients with coronary artery disease and healthy controls. The American journal of cardiology. 2008; 101:767773. [PubMed: 18328837] 
Krantz DS, Kop WJ, Santiago HT, Gottdiener JS. Mental stress as a trigger of myocardial ischemia and infarction. Cardiol Clin. 1996; 14:271-287. [PubMed: 8724559]

Mendham AE, Donges CE, Liberts EA, Duffield R. Effects of mode and intensity on the acute exercise-induced IL-6 and CRP responses in a sedentary, overweight population. European journal of applied physiology. 2011; 111:1035-1045. [PubMed: 21088973]

Mittleman MA, Maclure M, Sherwood JB, Mulry RP, Tofler GH, Jacobs SC, Friedman R, Benson H, Muller JE. Triggering of acute myocardial infarction onset by episodes of anger. Determinants of Myocardial Infarction Onset Study Investigators. Circulation. 1995; 92:1720-1725. [PubMed: 7671353]

Mittleman MA, Maclure M, Tofler GH, Sherwood JB, Goldberg RJ, Muller JE. Triggering of acute myocardial infarction by heavy physical exertion. Protection against triggering by regular exertion. Determinants of Myocardial Infarction Onset Study Investigators. The New England journal of medicine. 1993; 329:1677-1683. [PubMed: 8232456]

Moldoveanu AI, Shephard RJ, Shek PN. Exercise elevates plasma levels but not gene expression of IL-1beta, IL-6, and TNF-alpha in blood mononuclear cells. Journal of applied physiology (Bethesda, Md. : 1985). 2000; 89:1499-1504.

Pace TW, Mletzko TC, Alagbe O, Musselman DL, Nemeroff CB, Miller AH, Heim CM. Increased stress-induced inflammatory responses in male patients with major depression and increased early life stress. The American journal of psychiatry. 2006; 163:1630-1633. [PubMed: 16946190]

Pace TW, Negi LT, Adame DD, Cole SP, Sivilli TI, Brown TD, Issa MJ, Raison CL. Effect of compassion meditation on neuroendocrine, innate immune and behavioral responses to psychosocial stress. Psychoneuroendocrinology. 2009; 34:87-98. [PubMed: 18835662]

Pace TW, Negi LT, Sivilli TI, Issa MJ, Cole SP, Adame DD, Raison CL. Innate immune, neuroendocrine and behavioral responses to psychosocial stress do not predict subsequent compassion meditation practice time. Psychoneuroendocrinology. 2010; 35:310-315. [PubMed: 19615827]

Rosengren A, Spetz CL, Koster M, Hammar N, Alfredsson L, Rosen M. Sex differences in survival after myocardial infarction in Sweden; data from the Swedish National Acute Myocardial Infarction Register. Eur Heart J. 2001; 22:314-322. [PubMed: 11161950]

Ross R. The pathogenesis of atherosclerosis: a perspective for the 1990s. Nature. 1993; 362:801-809. [PubMed: 8479518]

Ross R. Atherosclerosis--an inflammatory disease. N Engl J Med. 1999; 340:115-126. [PubMed: 9887164]

Steptoe A, Hamer M, Chida Y. The effects of acute psychological stress on circulating inflammatory factors in humans: a review and meta-analysis. Brain, behavior, and immunity. 2007; 21:901-912.

Steptoe A, Owen N, Kunz-Ebrecht S, Mohamed-Ali V. Inflammatory cytokines, socioeconomic status, and acute stress responsivity. Brain, behavior, and immunity. 2002; 16:774-784.

Steptoe A, Willemsen G, Owen N, Flower L, Mohamed-Ali V. Acute mental stress elicits delayed increases in circulating inflammatory cytokine levels. Clinical science (London, England : 1979). 2001; 101:185-192.

Vaccarino V, Parsons L, Every NR, Barron HV, Krumholz HM. Sex-based differences in early mortality after myocardial infarction. National Registry of Myocardial Infarction 2 Participants. The New England journal of medicine. 1999; 341:217-225. [PubMed: 10413733]

Vaccarino V, Parsons L, Peterson ED, Rogers WJ, Kiefe CI, Canto J. Sex differences in mortality after acute myocardial infarction: changes from 1994 to 2006. Arch Intern Med. 2009; 169:1767-1774. [PubMed: 19858434]

Vaccarino V, Shah AJ, Rooks C, Ibeanu I, Nye JA, Pimple P, Salerno A, D’Marco L, Karohl C, Bremner JD, Raggi P. Sex differences in mental stress-induced myocardial ischemia in young survivors of an acute myocardial infarction. Psychosomatic medicine. 2014; 76:171-180. [PubMed: 24608039]

Walkers, F.; Soufer, R.; Zaret, BL. Nuclear cardiology. In: Braunwald, E.; Zipes, D.; Libby, P., editors. Heart Disease: A Text Book of Cardiovascular Medicine. Philadelphia, Pennsylvania: W.B. Saunders; 2000. p. 273-323. 
Woloshin S, Schwartz LM. Distribution of C-reactive protein values in the United States. The New England journal of medicine. 2005; 352:1611-1613. [PubMed: 15829550]

Wolpe, J. The practice of behavior therapy. Pergamon; 1973. 


\section{Highlights}

- Baseline IL-6 levels were higher in young women compared to age-matched men.

- IL-6 levels increased significantly after both mental and physical stress.

- Men and women had similar IL-6 responses to both mental and physical stress.

- After stress, IL-6 levels remained higher in young women compared to young men.

- Sex differences in IL-6 persisted after accounting for risk factors. 


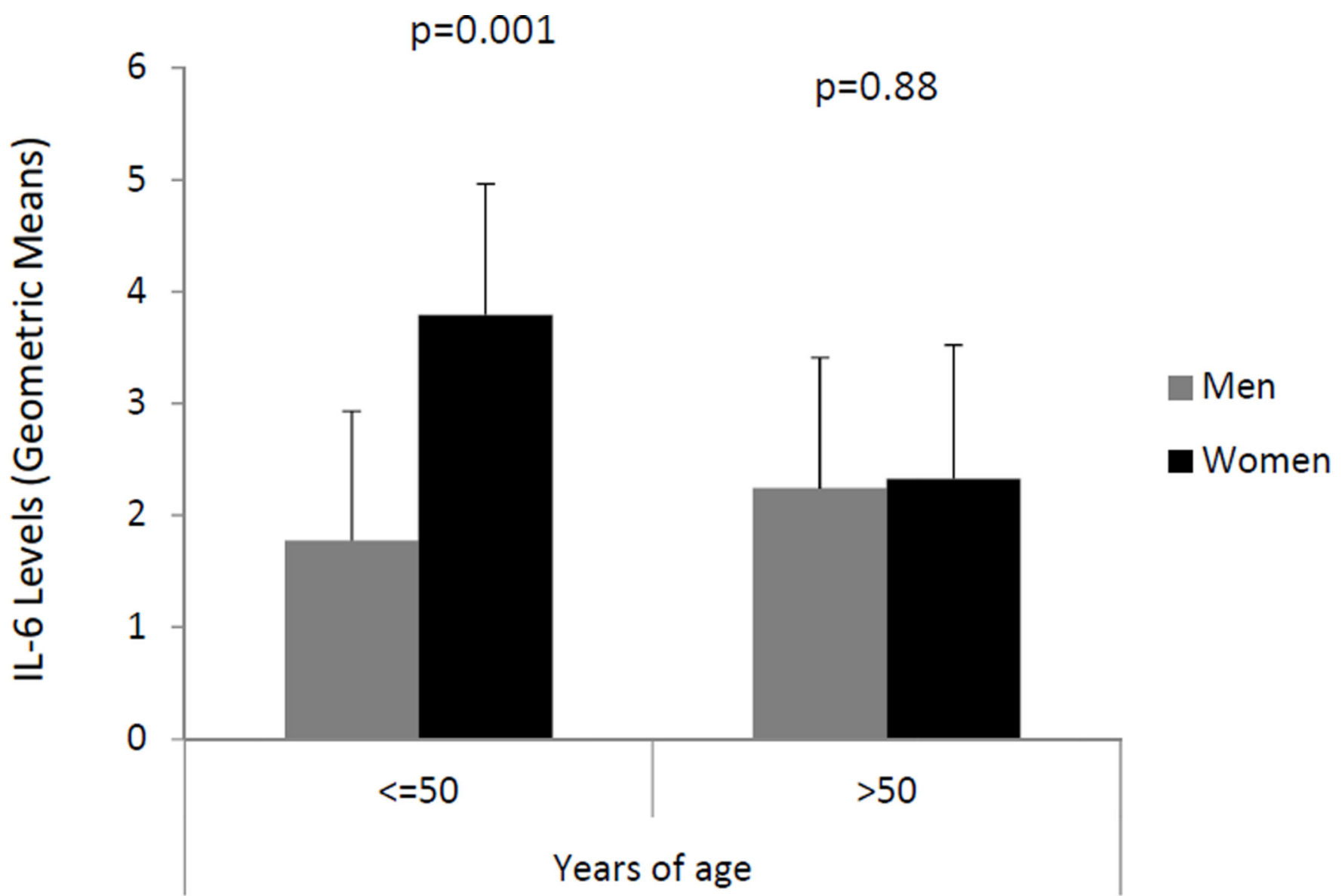

Figure 1.

Unadjusted baseline geometric mean plasma IL-6 concentrations in women and men by age. Values reported are geometric means. 
A

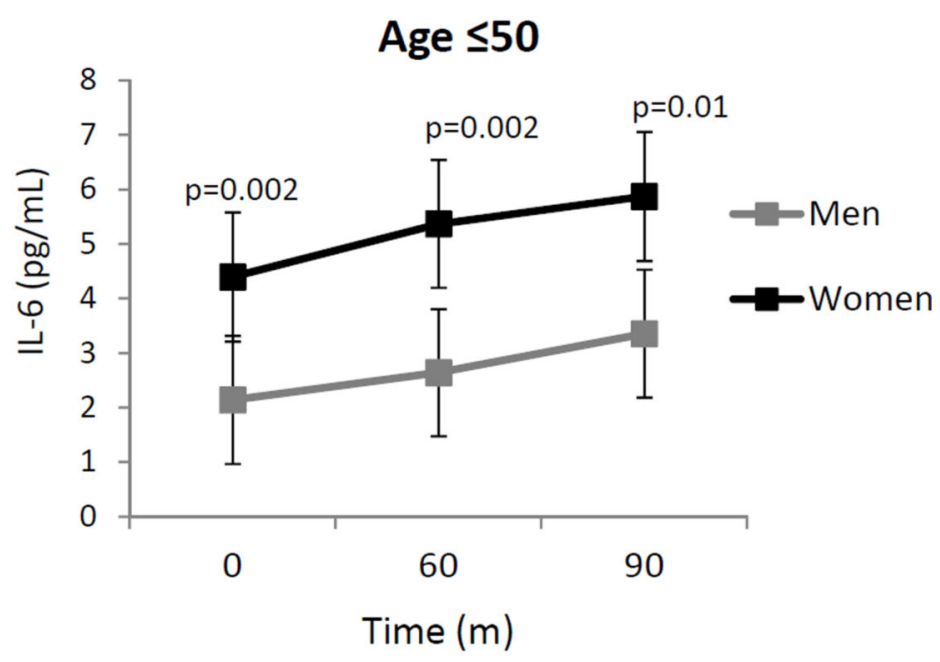

B

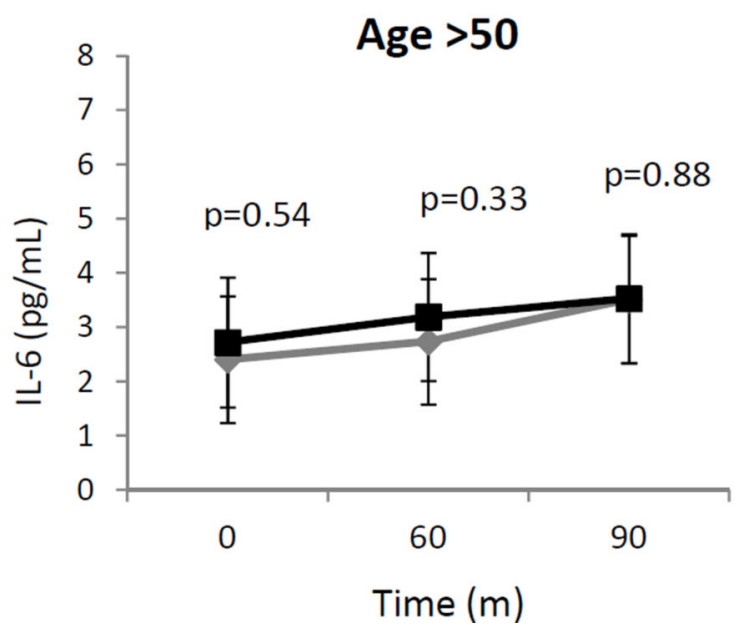

Figure 2.

Unadjusted geometric mean plasma IL-6 concentrations in women and men before and after mental stress. Values reported are geometric means. Results are stratified by age, $\mathbf{5 0}$ (a) and $>50(b)$. 
A

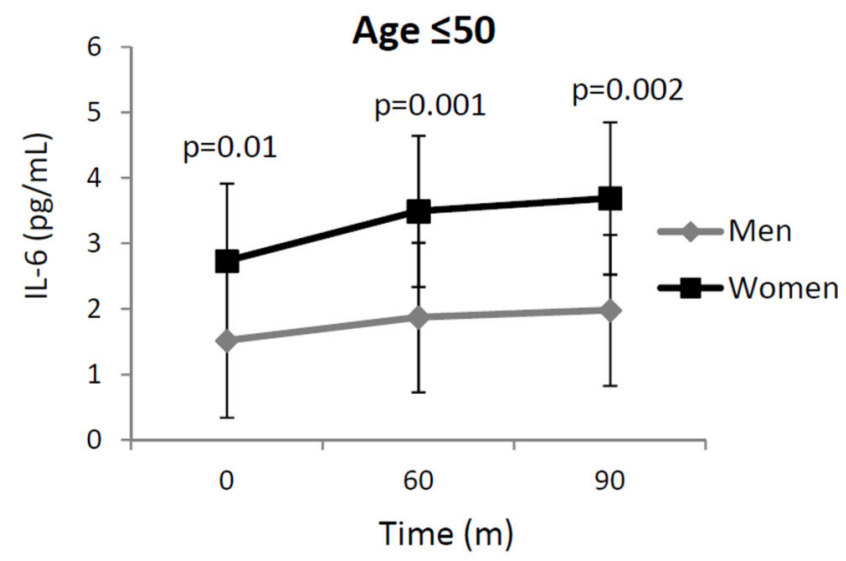

B

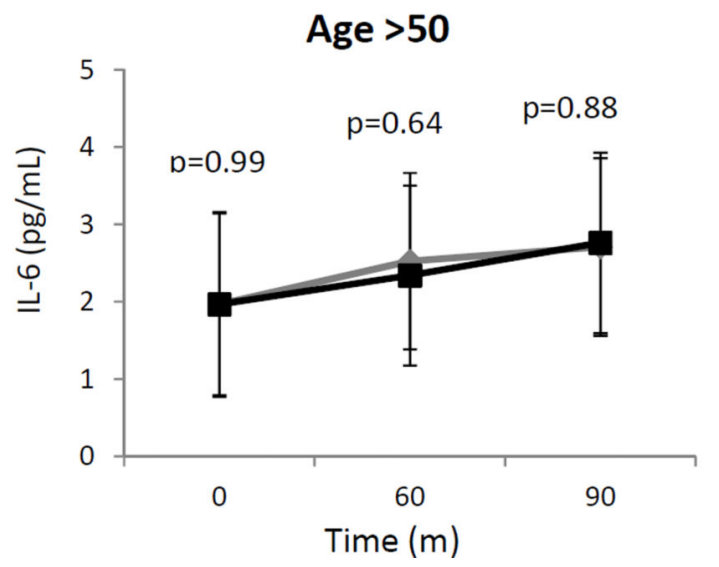

Figure 3.

Unadjusted geometric mean plasma IL-6 concentrations in women and men before and after physical stress. Values reported are geometric means. Results are stratified by age, $\mathbf{5 0}$ (a) and $>50(b)$. 


\section{Table 1}

Baseline mean IL-6 concentrations according to demographic, clinical, and lifestyle factors, and medication use.

\begin{tabular}{|c|c|c|c|c|}
\hline & & $\mathbf{N}$ & $\begin{array}{c}\text { Mean IL-6 } \\
(\mathrm{pg} / \mathrm{ml})(\mathbf{9 5 \%} \mathrm{CI})\end{array}$ & p-value \\
\hline \multicolumn{5}{|l|}{ Demographic Factors } \\
\hline Age & $\begin{array}{l}50 \text { years } \\
>50 \text { years }\end{array}$ & $\begin{array}{l}49 \\
49\end{array}$ & $\begin{array}{l}2.53(2.00-3.19) \\
2.28(1.80-2.89)\end{array}$ & 0.53 \\
\hline Completed high school & $\begin{array}{l}\text { No } \\
\text { Yes }\end{array}$ & $\begin{array}{l}42 \\
56\end{array}$ & $\begin{array}{l}3.22(2.53-4.12) \\
1.94(1.58-2.39)\end{array}$ & 0.002 \\
\hline $\begin{array}{l}\text { Income below poverty level } \\
(\$ 20,000), \%\end{array}$ & $\begin{array}{l}\text { No } \\
\text { Yes }\end{array}$ & $\begin{array}{l}31 \\
65\end{array}$ & $\begin{array}{l}3.22(2.40-4.31) \\
2.19(1.81-2.65)\end{array}$ & 0.03 \\
\hline Married, \% & $\begin{array}{l}\text { No } \\
\text { Yes }\end{array}$ & $\begin{array}{l}58 \\
40\end{array}$ & $\begin{array}{l}2.61(2.11-3.24) \\
2.13(1.65-2.76)\end{array}$ & 0.23 \\
\hline Black race, $\%$ & $\begin{array}{l}\text { No } \\
\text { Yes }\end{array}$ & $\begin{array}{l}45 \\
53\end{array}$ & $\begin{array}{l}1.92(1.51-2.45) \\
2.90(2.33-3.60)\end{array}$ & 0.01 \\
\hline \multicolumn{5}{|l|}{ Clinical and Lifestyle Factors } \\
\hline Systolic blood pressure & $\begin{array}{l}<120 \mathrm{mmHg} \\
\geq 120 \mathrm{mmHg}\end{array}$ & $\begin{array}{l}47 \\
49\end{array}$ & $\begin{array}{l}2.53(2.01-3.20) \\
2.39(1.90-3.00)\end{array}$ & 0.72 \\
\hline Diastolic blood pressure & $\begin{array}{l}<74 \mathrm{mmHg} \\
\geq 74 \mathrm{mmHg}\end{array}$ & $\begin{array}{l}48 \\
48\end{array}$ & $\begin{array}{l}2.35(1.87-2.97) \\
2.56(2.04-3.22)\end{array}$ & 0.61 \\
\hline Plasma glucose & $\begin{array}{l}<93 \mathrm{mg} / \mathrm{dL} \\
293 \mathrm{mg} / \mathrm{dL}\end{array}$ & $\begin{array}{l}47 \\
46\end{array}$ & $\begin{array}{l}2.43(1.92-3.06) \\
2.49(1.98-3.13)\end{array}$ & 0.87 \\
\hline HDL cholesterol & $\begin{array}{l}<45 \mathrm{mmol} / \mathrm{L} \\
\geq 45 \mathrm{mmol} / \mathrm{L}\end{array}$ & $\begin{array}{l}43 \\
55\end{array}$ & $\begin{array}{l}2.38(1.87-3.01) \\
2.53(2.02-3.17)\end{array}$ & 0.70 \\
\hline LDL cholesterol & $\begin{array}{l}<89 \mathrm{mmol} / \mathrm{L} \\
289 \mathrm{mmol} / \mathrm{L}\end{array}$ & $\begin{array}{l}46 \\
46\end{array}$ & $\begin{array}{l}2.24(1.78-2.83) \\
2.69(2.13-3.39)\end{array}$ & 0.27 \\
\hline Gensini score & $\begin{array}{l}<32 \\
\geq 32\end{array}$ & $\begin{array}{l}43 \\
55\end{array}$ & $\begin{array}{l}2.36(1.82-3.05) \\
2.44(1.96-3.04)\end{array}$ & 0.84 \\
\hline $\begin{array}{l}\text { Left ventricular ejection } \\
\text { fraction }\end{array}$ & $\begin{array}{l}<40 \% \\
\geq 40 \%\end{array}$ & $\begin{array}{l}17 \\
81\end{array}$ & $\begin{array}{l}2.29(1.55-3.39) \\
2.43(2.02-2.93)\end{array}$ & 0.78 \\
\hline Previous revascularization, $\%$ & $\begin{array}{l}\text { No } \\
\text { Yes }\end{array}$ & $\begin{array}{l}14 \\
84\end{array}$ & $\begin{array}{l}1.78(1.14-2.78) \\
2.52(2.11-3.01)\end{array}$ & 0.15 \\
\hline Hypertension, $\%$ & $\begin{array}{l}\text { No } \\
\text { Yes }\end{array}$ & $\begin{array}{l}30 \\
67\end{array}$ & $\begin{array}{l}2.42(1.83-3.20) \\
2.48(2.02-3.03)\end{array}$ & 0.90 \\
\hline Diabetes mellitus, $\%$ & $\begin{array}{l}\text { No } \\
\text { Yes }\end{array}$ & $\begin{array}{l}77 \\
20\end{array}$ & $\begin{array}{l}2.42(2.02-2.91) \\
2.61(1.80-3.78)\end{array}$ & 0.72 \\
\hline Hyperlipidemia, \% & $\begin{array}{l}\text { No } \\
\text { Yes }\end{array}$ & $\begin{array}{l}26 \\
71\end{array}$ & $\begin{array}{l}2.45(1.80-3.32) \\
2.46(2.02-2.99)\end{array}$ & 0.97 \\
\hline Obese (BMI 230 ), $\%$ & $\begin{array}{l}\text { No } \\
\text { Yes }\end{array}$ & $\begin{array}{l}74 \\
23\end{array}$ & $\begin{array}{l}2.19(1.82-2.62) \\
3.47(2.54-4.76)\end{array}$ & 0.01 \\
\hline $\begin{array}{l}\text { Subjective Units of Distress } \\
\text { Scale }\end{array}$ & $\begin{array}{l}<5 \\
\square 6\end{array}$ & $\begin{array}{l}48 \\
48\end{array}$ & $\begin{array}{l}2.63(2.09-3.32) \\
2.25(1.78-2.83)\end{array}$ & 0.34 \\
\hline Depressive symptoms & $\begin{array}{l}<9 \\
\geq 9\end{array}$ & $\begin{array}{l}50 \\
48\end{array}$ & $\begin{array}{l}2.12(1.68-2.67) \\
2.75(2.17-3.48)\end{array}$ & 0.12 \\
\hline Duke Activity Status Index & $\begin{array}{l}<3 \\
\geq 3\end{array}$ & $\begin{array}{l}56 \\
42\end{array}$ & $\begin{array}{l}2.75(2.21-3.42) \\
2.01(1.57-2.59)\end{array}$ & 0.06 \\
\hline Current smoker, $\%$ & $\begin{array}{l}\text { No } \\
\text { Yes }\end{array}$ & $\begin{array}{l}70 \\
28\end{array}$ & $\begin{array}{l}2.22(1.84-2.69) \\
3.05(2.19-4.24)\end{array}$ & 0.10 \\
\hline $\begin{array}{l}\text { Lifetime history of alcohol } \\
\text { abuse, \% }\end{array}$ & $\begin{array}{l}\text { No } \\
\text { Yes }\end{array}$ & $\begin{array}{l}76 \\
22\end{array}$ & $\begin{array}{l}2.45(2.03-2.97) \\
2.25(1.59-3.20)\end{array}$ & 0.67 \\
\hline
\end{tabular}




\begin{tabular}{lcccc}
\hline & & $\mathbf{N}$ & $\begin{array}{c}\text { Mean IL-6 } \\
(\mathbf{p g} / \mathbf{m l})(\mathbf{9 5 \%} \mathbf{C I})\end{array}$ & p-value \\
\hline $\begin{array}{l}\text { Lifetime history of } \\
\text { substance abuse, \% }\end{array}$ & No & 49 & $2.48(1.95-3.14)$ & 0.73 \\
Medications, \% & Yes & 49 & $2.33(1.84-2.96)$ & \\
Statins & & & & \\
& No & 12 & $2.21(1.39-3.49)$ & 0.62 \\
Beta blockers & Yes & 85 & $2.50(2.09-2.97)$ & \\
& No & 12 & $2.04(1.29-3.22)$ & 0.39 \\
Ace- inhibitors & Yes & 85 & $2.53(2.12-3.01)$ & \\
& No & 44 & $2.21(1.74-2.80)$ & 0.23 \\
Aspirin & Yes & 53 & $2.70(2.16-3.37)$ & \\
& No & 12 & $3.39(2.15-5.33)$ & 0.14 \\
\hline
\end{tabular}

Values presented are geometric mean baseline IL-6 concentrations and 95\% confidence intervals. Continuous variables are dichotomized by median split. P-values were calculated using mixed model analysis. 


\section{을}

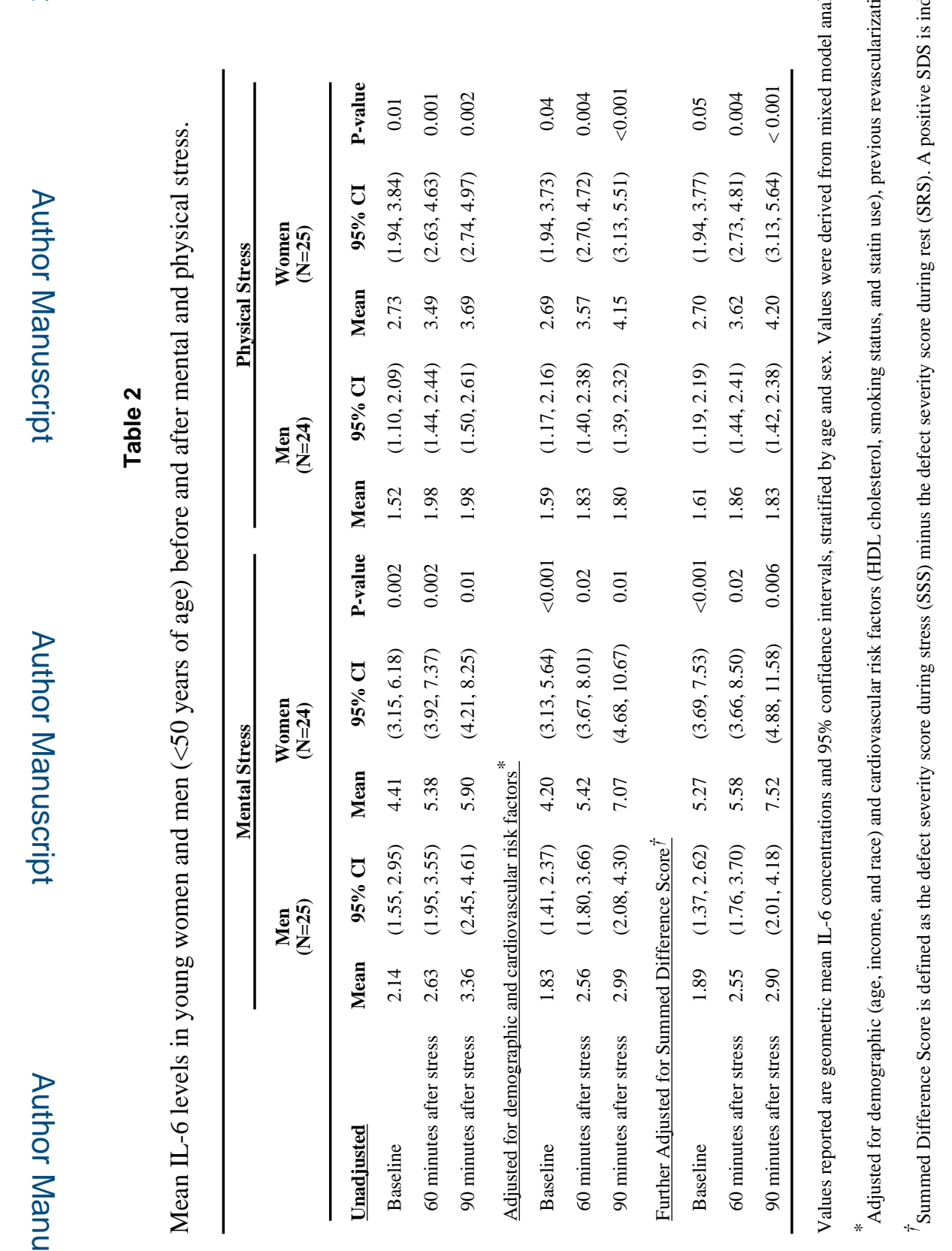

Brain Behav Immun. Author manuscript; available in PMC 2017 January 01. 